\title{
Managing without default retirement in universities: a comparative picture from Australia
}

The abolition of the default retirement age is creating challenges for UK employers, and universities in particular. Operating without mandatory retirement may have consequences for performance management, the creation of opportunities for new generations of workers, the scope for workforce planning and employment costs. Drawing on comparative experiences of Australian universities, which have been operating without mandatory retirement since the 1990s, this article critically examines whether these consequences have materialised in Australia. It draws out a number of lessons for UK universities from the Australian experience.

\section{1) Introduction}

In 2011 the UK Coalition government changed the face of retirement policy almost overnight by abolishing the national default retirement age ('DRA'). While employers may still adopt an Employer-Justified Retirement Age ('EJRA') to manage the end of the employment relationship, there remains significant uncertainty regarding when a retirement age will be 'justified', leaving many employers in a state of limbo. Indeed, anecdotal evidence indicates that many employers are choosing to abandon fixed retirement ages rather than risk a legal challenge from retired employees. ${ }^{1}$ UK employers therefore now face a brave new world of workplace relations, where retirement must generally be managed on a case-by-case basis and negotiated with individual employees.

\footnotetext{
${ }^{1}$ DWF 'De-regulation of retirement - one year on' (9 May 2012) <http://www.dwf.co.uk/insight/legalupdates/deregulation-of-retirement-one-year-on> accessed 15 May 2012. The key exceptions being the University of Oxford and the University of Cambridge, which have chosen to adopt employer-justified retirement ages. See further below.
} 
These changes are particularly significant for universities. Academic work is intrinsically rewarding and involves few physical demands, meaning many academics wish to continue their employment into old age. ${ }^{2}$ In a survey of academic staff at 12 UK higher education institutions, $29 \%$ indicated that they would prefer to retire over the age of 65 and 36\% expected to retire after the age of $65 .^{3}$ Therefore, a significant proportion of academic staff are likely to continue to work beyond a traditional retirement age of 65 if a DRA is not imposed. ${ }^{4}$

At the same time, there is concern that UK universities lack the human resource practices to manage an ageing academic workforce without a DRA. Prior to the abolition of the DRA, many UK higher education employers used mandatory retirement for their academic staff, and few accepted requests to continue to work beyond the DRA. ${ }^{5}$ The abolition of the DRA may therefore raise challenges for UK universities, particularly in relation to the performance management of academic staff, the creation of opportunities for new generations of

\footnotetext{
${ }^{2}$ See, for example, L Rosenman and S McDonald 'How should universities respond to the abolition of compulsory retirement?' (1995) 38 Australian Universities' Review 63, p 63.

${ }^{3} \mathrm{~S}$ Manfredi and L Vickers 'Retirement and age discrimination: managing retirement in higher education' (2009) 38 Ind Law J 343, p 357.

${ }^{4}$ Ibid, p 356; see also C Moughton and S Manfredi 'Managing flexible retirement and extended working lives: a resource guide' (Oxford: 2011) p 5.

${ }^{5}$ Manfredi and Vickers, above n 3, p 364; cf S Manfredi and L Vickers 'Pensioning off the mandatory retirement age: implications for the higher education sector' (2013) 33 LS 289, p 293. Under the Employment Equality (Age) Regulations 2006, SI 2006/1031, employers were required to consider an employee's request to work beyond the retirement age and could only retire an employee in accordance with complicated procedural provisions (reg 47, Sch 6). For further description and critique of these provisions, see C Kilpatrick 'The new UK retirement regime, employment law and pensions' (2008) 37 Ind Law J 1. While universities accepted few requests to continue working, this may also be attributable to the relatively low number of requests received by each institution: Manfredi and Vickers, p 292.
} 
academics and the scope for workforce planning. In this context, it is important to consider whether these challenges will actually materialise for UK universities in the coming years.

To explore these issues, this article considers comparative experiences of Australian universities, which have been operating without fixed retirement ages since the 1990s. Australian and UK universities 'share common roots and common recent problems'. ${ }^{6}$ While there are clear differences between the two countries, it is informative to consider how a comparative jurisdiction has responded to the ageing academic workforce and comparative lessons for UK universities. This article commences with a legal doctrinal analysis of retirement ages in the UK and Australia (Parts 2 and 4a), and a review of potential issues arising from the abolition of the UK DRA in 2011 (Part 3). It then considers the consequences of the abolition of retirement ages for Australian universities, drawing on statistical evidence, academic literature, interviews with the National Tertiary Education Union ('NTEU') ${ }^{7}$ and organisational case studies of six Australian universities, to obtain a picture of the sector-wide and organisational consequences of abolishing mandatory retirement (Part 4b). Finally, in Part 5 the article outlines the ways in which the Australian experience may inform UK universities' responses to the abolition of the DRA.

\section{2) Abolition of the UK default retirement age}

Prior to 2006, UK employers choosing to implement a normal retirement age ('NRA') for their workforce were protected by legislation, with employees dismissed on the ground of retirement after reaching the NRA or age 65 being unable to claim unfair dismissal or

\footnotetext{
${ }^{6}$ See, for example, N Barr 'Higher education in Australia and Britain: what lessons?' (1998) 31 Australian Economic Review 179.

${ }^{7}$ The union for tertiary education workers in Australia.
} 
redundancy payments. ${ }^{8}$ Protection of retirement ages was retained upon the introduction of age discrimination legislation in the UK: with the passing of the Employment Equality (Age) Regulations 2006, SI 2006/1031, an exception was made allowing for dismissal on the basis of retirement for workers at or over the age of 65 , creating a national default retirement age (the DRA) (reg 30). Employers were also able to retain a NRA lower than 65 if it could be objectively justified.

In January 2011, the UK government announced its intention to phase out the DRA from April 2011, and passed the Employment Equality (Repeal of Retirement Age Provisions) Regulations 2011, SI 2011/1069 (the 2011 Regulations) to facilitate the change. From 1 October 2011, it has no longer been possible to retire an employee using the DRA. The 2011 Regulations also removed retirement as a fair reason for dismissal in the Employment Rights Act 1996. Under the new Regulations, employers may still implement an employer-justified retirement age ('EJRA') so long as the requirement can be objectively justified as a proportionate means of achieving a legitimate aim.

There is significant legal uncertainty regarding when an EJRA will be 'justified'. 9 The case of Seldon v Clarkson Wright \& Jakes (A partnership) ${ }^{10}$ provides some limited clarification of the law in this area. In that case, the UK Supreme Court considered the appeal of a solicitor who claimed he was subject to direct age discrimination when compulsorily retired from the partnership at age 65 in accordance with the partnership deed. While Mr. Seldon was retired

\footnotetext{
${ }^{8}$ Employment Rights Act 1996, s 109.

${ }^{9}$ For further discussion of these legislative and judicial developments, see Manfredi and Vickers above n 5, pp 299-308.

${ }^{10}$ [2012] 2 CMLR 50 ('Seldon').
} 
prior to the abolition of the DRA, the DRA did not apply to members of a partnership ${ }^{11}$ therefore, retirement under the partnership deed had to be justified as necessary and proportionate in the interests of the partnership (the same test that now applies to all retirement ages). The issues to be considered by the Supreme Court included: (1) whether the aims identified by the employment tribunal ('ET') were capable of being legitimate aims; (2) whether the firm had to justify the application of the retirement clause in this particular case; and (3) whether relying on the retirement clause in this case was a proportionate means of achieving those aims.

In relation to point (1), the Court concluded that the UK had decided to give employers and partnerships the flexibility to choose which objectives to pursue, so long as these objectives: (a) could count as 'legitimate objectives of a public interest nature'; (b) were consistent with the state's social policy aims; and (c) the means used to achieve the objectives were proportionate. Therefore, while it is for states to identify broad social policy aims, employers may articulate and apply those aims as they relate to their particular circumstances. This interpretation of 'legitimate aims' appears inconsistent with Article 6(1) of the Framework Directive, which provides that Member States, as opposed to employers, may provide that differences of treatment on the grounds of age shall not constitute discrimination. ${ }^{12}$

In considering the case law of the CJEU, the UK Supreme Court categorised legitimate aims as falling within two broad classes: first, intergenerational fairness; and, second, dignity. ${ }^{13}$ In relation to the actual aims identified by the ET in this case - ensuring associates were given

\footnotetext{
${ }^{11}$ Regulation 30, which established the DRA, provided that employees at or over the age of 65 could be dismissed on the basis of retirement. In the Seldon case, the firm's partnership deed applied to partners (not employees). Therefore, the DRA and reg 30 did not apply.

${ }^{12}$ See further C Barnard 'Retiring gracefully' (2011) 70 Cambridge Law Journal 304, p 306.

${ }^{13}$ Seldon v Clarkson Wright \& Jakes (A partnership) [2012] 2 CMLR 50, [56]-[57].
} 
the opportunity of partnership after a reasonable period; facilitating workforce planning; and limiting the need to use performance management to remove partners, thereby contributing to the firm's 'congenial and supportive culture' - the Court noted that each had been recognised by the CJEU as legitimate social policy aims. The aims could also be related to the circumstances of the firm, making them legitimate in this particular case. ${ }^{14}$ Lord Hope noted that while the aims were directed to the firm's own best interests, this did not prevent them being legitimate social policy aims.

In relation to the second issue to be considered by the Supreme Court (whether the firm had to justify the application of the retirement clause in that particular case), the Court held that where a general rule is justified, the application of the rule to a specific case would also generally be justified. Therefore, a rule will only need to be justified in the particular circumstances of the business, not upon each application of the rule. As a result, the firm did not need to justify the application of the retirement rule to Mr. Seldon personally.

Finally, in relation to point (3) (whether relying on the retirement clause was a proportionate means of achieving those aims), the Court held that the ET had not considered whether a retirement age of 65 was proportionate, as opposed to a retirement age more broadly: 'there is a difference between justifying $a$ retirement age and justifying this retirement age'. ${ }^{15}$ The case was referred back to the ET to consider this question.

In May 2013, the ET held that the partnership's retirement age of 65 was appropriate and reasonably necessary for achieving the aims of staff retention and planning for the future of

\footnotetext{
${ }^{14}$ Ibid, [67].

${ }^{15}$ Ibid, [68].
} 
the firm. ${ }^{16}$ Associates 'should see that upon the retirement of partners opportunities were created for succession to partnership ${ }^{17}$ and that there was a 'realistic long-term expectation as to when and where vacancies will arise'. ${ }^{18}$ In deciding whether the age of 65 was proportionate, the ET considered the importance of consent, the existence of the DRA, the state pension age ('SPA'), and the fact that the CJEU had considered 65 to be a proportionate age in the past. However, the ET also noted that the position 'might have been different' if Mr. Seldon had been retired after abolition of the DRA and planned changes to the SPA. ${ }^{19}$ The ET's decision on proportionality was upheld by the EAT in May $2014 .^{20}$

The Seldon decision means employers will be able to identify legitimate aims to support a retirement policy fairly readily, so long as those aims are relevant to their particular circumstances. This will be particularly straightforward where the organisation has a hierarchy with limited senior positions, as in a law firm or university. However, it will be more challenging to prove that the actual retirement age adopted is a proportionate means of achieving these aims. Following the abolition of the DRA, employers may find it difficult to justify 65 as a proportionate retirement age, as the government has deemed a DRA of 65 not to be appropriate for the general workforce. The ET's further consideration of the Seldon case has provided limited guidance on this issue, as the DRA was still in place at the time of Mr. Seldon's retirement. The ET's decision on proportionality is limited to a particular historical moment, before the introduction of the 2011 Regulations and changes to the SPA. Indeed, the ET explicitly acknowledged the relevance of the DRA and SPA to the issue of proportionality: 'The determination of the issue is relevant only to the difference in treatment

\footnotetext{
${ }^{16}$ The collegiality aim was not raised due to a lack of evidence (at [8], [36]).

${ }^{17}$ Seldon v Clarkson Wright \& Jakes [2013] UKET 1100275/2007 (14 May 2013) [76].

${ }^{18}$ Ibid, [77].

${ }^{19}$ Ibid, [92].

${ }^{20}$ Seldon v Clarkson Wright \& Jakes [2014] UKEAT/0434/13/RN (13 May 2014).
} 
as applied to the Claimant at the relevant time.... ${ }^{21}$ Given most employers have only needed to justify an EJRA since the passing of the 2011 Regulations, ${ }^{22}$ Seldon provides limited meaningful guidance on the proportionality issue. Thus, there remains significant legal uncertainty regarding when a retirement age will be justified.

Perhaps as a consequence, employers appear unwilling to risk relying on fixed retirement ages. A 2013 Eversheds survey of 307 employers found that $2.9 \%$ of respondents had retained a policy of mandatory retirement (compared with $69 \%$ in a similar survey in 2011). ${ }^{23}$ Further, $72 \%$ of respondents attributed their change of policy to the repeal of the DRA. ${ }^{24}$ While employers had changed their policies in response to the 2011 Regulations, many did not feel positively about the change: $34 \%$ of respondents felt the abolition of the DRA had a negative or very negative impact on their organisation (compared with $14 \%$ who felt it had been positive); and $48 \%$ thought the DRA should be reinstated (compared to $43 \%$ who thought the law should remain as is). ${ }^{25}$ In contrast, the 2013 State of HR survey conducted by Speechly Bircham and King's College London found that $19 \%$ of respondents had retained a retirement age for their workforce, the majority of whom failed to provide a justification for their retirement age when asked. ${ }^{26}$

While these surveys indicate that employers are abandoning fixed retirement ages, they are not indicative of the UK as a whole. Both surveys had significant sampling issues: the

\footnotetext{
${ }^{21}$ Seldon v Clarkson Wright \& Jakes [2013] UKET 1100275/2007 (14 May 2013) [64], [92].

${ }^{22}$ Though retirement ages under 65 also needed to be justified prior to the 2011 Regulations.

${ }^{23}$ Eversheds 'Eversheds UK HR e-briefing: how are employers managing without the default retirement age?' (London: 2013) p 2.

24 Ibid.

${ }^{25}$ Ibid, pp 6-7.

${ }^{26} \mathrm{R}$ Thomas and others 'Recovery in sight? The state of HR' (London: 2013) p 9.
} 
Eversheds survey was sent to recipients of the law firm's e-briefings newsletter (who are mostly likely to be large employers); ${ }^{27}$ and the State of HR survey was advertised online and emailed to a purchased list of senior HR contacts, and clients and contacts of Speechly Bircham and King's College London. ${ }^{28}$ Neither survey had a randomly selected nor specifically stratified sample and response rates are not available or applicable. It therefore remains unclear how far these trends extend and, indeed, whether they are trends at all.

At the same time, anecdotal evidence from the UK university sector indicates that most universities have chosen to abandon fixed retirement ages, with the notable exceptions of the Universities of Oxford and Cambridge, which have elected to adopt an EJRA of 67 for academic staff. ${ }^{29}$ Given many UK universities applied mandatory retirement policies to their academic staff prior to the abolition of the DRA, and had limited experience of allowing staff to work beyond the DRA, ${ }^{30}$ this change may raise significant challenges for UK universities.

\section{3) Potential challenges of operating without a DRA}

In the government consultation process prior to the abolition of the DRA, respondents expressed concerns regarding how workplaces would operate without mandatory retirement. In particular, respondents felt abolition of the DRA would lead to:

- an increase in the number of age discrimination claims;

\footnotetext{
${ }^{27}$ Eversheds, above n 23, p 1.

${ }^{28}$ Email from Michael Clinton '5th Annual State of HR Survey' (21 May 2013).

${ }^{29}$ Human Resources Division, University of Cambridge 'Retirement policy' (University of Cambridge, 11 June 2012) <http://www.admin.cam.ac.uk/offices/hr/policy/retirement/> accessed 24 September 2013; Personnel Services, University of Oxford 'Employer justified retirement age' (University of Oxford, 22 April 2013) <http://www.admin.ox.ac.uk/personnel/end/retirement/acrelretire/ejra/> accessed 24 September 2013.

${ }^{30}$ Manfredi and Vickers, above n 3, p 364.
} 
- an increase in the use of, and dismissals based on, capability and performance measures;

- difficulties in workplace and succession planning; and

- a negative impact on younger workers. ${ }^{31}$

In its response to the consultation, the government dismissed these concerns, stating that:

The Government does not believe that the abolition of the DRA will have a negative impact on opportunities for younger workers. ... the effect on economic activity and labour supply of removing the DRA is likely to increase economic activity in the economy as a whole. Furthermore, it is not often the case that younger and older workers are direct substitutes. Where there are genuine succession planning considerations (perhaps involving particular training requirements) employers could consider retaining a retirement age if it can be objectively justified.

We agree that there is likely to be some limited increase in the use of capability procedures, which in turn is likely to lead to a number of Tribunal cases .... However, the removal of [the existing retirement procedures] will eliminate the current risk of cases being brought against employers on purely procedural grounds. The Government believes that performance management of staff should be carried out consistently and objectively for all staff, irrespective of age. ${ }^{32}$

\footnotetext{
${ }^{31}$ BIS 'Phasing out the default retirement age: government response to consultation' (London: 2011) URN 11/536 pp 3, 6 .

${ }^{32}$ Ibid, p 7.
} 
The Eversheds survey (discussed above) provides some indication of the extent to which the respondents' concerns have materialised in practice. As Table 1 demonstrates, a substantial proportion of employer respondents experienced negative impacts from the abolition of the DRA. However, these negative impacts are partly balanced by positive impacts experienced by other respondents, as illustrated by Table 2 .

\section{Table 1 about here}

\section{Table 2 about here}

The Eversheds results provide an early snapshot of how some UK employers are experiencing the abolition of the DRA. It remains to be seen whether these trends continue after the change has been 'bedded down', and whether a broader sample of employers are experiencing the same issues. Given these challenges appear to be real issues for some employers, it is worth considering whether they are likely to have any particular impact in the university sector.

\section{a) Declining capacity and the need for performance management}

The government and respondents to the government consultation both recognised that the abolition of the DRA was likely to lead to an increase in the use of, and dismissals based on, capability and performance measures. ${ }^{33}$ Some UK universities believe that the removal of mandatory retirement will 'induce more robust performance management'. ${ }^{34}$ At the same time, universities have traditionally lacked effective procedures for performance

\footnotetext{
${ }^{33}$ Ibid, pp 3, 6.

${ }^{34}$ Manfredi and Vickers, above n 5, p 295.
} 
management, particularly for academic staff. The (dated) Bett review of pay and conditions in UK universities identified the human resource ('HR') function 'as an area of particular weakness that merited concerted action'. ${ }^{35}$ Government action to promote the development of university HR processes appears to have had limited effect in relation to performance management: ${ }^{36}$ in a 2006 survey of UK university HR directors, performance management was the 'new initiative or practice' respondents would most like to have introduced at their university, ${ }^{37}$ indicating that at least $51 \%$ of respondents felt that their performance management practices needed enhancement. Indeed, the HR practices that respondents rated as least effective in their institutions were performance management, staff planning/succession planning and managing poor performance. ${ }^{38}$ This implies that an increased emphasis on performance management for older workers could prove challenging for UK universities. ${ }^{39}$

That said, we may question the assumed relationship between the abolition of the DRA and the increase in the use of performance management, which also assumes an association between ageing and declining capacity. ${ }^{40}$ Analysing submissions to the government consultation on the Employment Equality (Age) Regulations 2006, SI 2006/1031, Sargeant

\footnotetext{
${ }^{35}$ D E Guest and M Clinton 'Human resource management and university performance: final report' (London: 2007) p 6.

${ }^{36}$ Ibid.

${ }^{37}$ Ibid, p 22.

${ }^{38}$ Ibid, p 2.

${ }^{39}$ At the same time, some UK universities have well-developed performance management programmes, such as the University of London's central Performance Management Framework and that at the University of Gloucestershire: see further Moughton and Manfredi, above n 4, p 25.

${ }^{40}$ B Bytheway 'Ageism' in M L Johnson and others (eds), The Cambridge Handbook of Age and Ageing (Cambridge: Cambridge University Press, 2005) p 339; C Duncan 'The dangers and limitations of equality agendas as means for tackling old-age prejudice' (2008) 28 Ageing \& Society 1133, p 1143. That said, performance management may also benefit older workers who are good performers.
} 
identifies a prevailing assumption amongst employers that 'older workers would decline in competence and capability as they aged'. ${ }^{41}$ This reflects a decline theory of ageing, which neglects to consider potential benefits of the ageing process ${ }^{42}$ and the social construction of age and ageing. ${ }^{43}$ Assumptions regarding the relationship between age and competence are normally underpinned by ageist beliefs about how individuals vary biologically as the result of the ageing process. ${ }^{44}$ Chronological age is a weak predictor of an individual's capacity to work productively ${ }^{45}$ and age is not a good proxy for capability. ${ }^{46}$ If anything, older workers form a more heterogeneous group than younger workers, as people age at different rates. ${ }^{47}$

Further, the performance of academic staff may not decline significantly with age. Longitudinal studies have found two key requirements for maintaining high cognitive performance in later life, namely a high level of education in early life, and ongoing intellectual activity in older age. ${ }^{48}$ University academics likely satisfy both these requirements, reducing any link between declining capability and age. Management attitudes

\footnotetext{
${ }^{41}$ M Sargeant 'The default retirement age: legitimate aims and disproportionate means' (2010) 39 Ind Law J $244, \mathrm{p} 250$.

${ }^{42}$ See, for example, K W Schaie 'Ageing, Theories of', International Encyclopedia of the Social and Behavioral $\begin{array}{lllllll}\text { Sciences } & \text { (Elsevier } & \text { Science } & \text { Ltd, } & \text { 2001) } & 317 & \text { p }\end{array}$ $<$ http://www.uwpsychiatry.org/sls/publications/Theories_aging.pdf> accessed 16 November 2011; Moughton and Manfredi, above n 4, p 25.

${ }^{43}$ Schaie, above n 42 , p 320.

${ }^{44}$ Bytheway, above $\mathrm{n} 40, \mathrm{p} 339$.

${ }^{45}$ See, for example, S A Bass and F G Caro 'Productive aging: a conceptual framework' in N Morrow-Howell, J Hinterlong and M W Sherraden (eds), Productive Aging: Concepts and Challenges (Baltimore: John Hopkins Press, 2001) p 40.

${ }^{46} \mathrm{~S}$ Fredman 'The age of equality' in S Fredman and S Spencer (eds), Age as an Equality Issue: Legal and Policy Perspectives (Oxford: Hart, 2003) p 40.

${ }^{47} \mathrm{~J}$ G Evans 'Age discrimination: implications of the ageing process' in S Fredman and S Spencer (eds), Age as an Equality Issue: Legal and Policy Perspectives (Oxford: Hart, 2003) p 16.

${ }^{48}$ P G Koopman-Boyden and L Macdonald 'Ageing, work performance and managing ageing academics' (2003) 25 J HE Policy and Management 29, p 31.
} 
and workplace culture may have a far more direct impact on the performance of older workers than chronological ageing. ${ }^{49}$

While ageing may not result in a decline in work performance, a renewed focus on performance management in universities may increase the intensification of work more generally, undermining the quality of employment for many academics. In Australia, the NTEU 'has a long held belief' that performance management and its corollary, performancebased pay schemes, 'are merely devises [sic] seeking to intensify the work effort and increase the control of management ${ }^{50}$ Whether this is occurring in practice is explored further below.

\section{b) Sharing opportunities across generations}

The UK government has repeatedly rejected claims that the abolition of the DRA will reduce opportunities for younger workers:

The employment of older workers should not be seen as a 'younger versus older' battle for jobs. Some people mistakenly believe that productive older workers should make way for younger workers and 'free up the job market' but the facts show this can create further problems for both the business and the wider labour market. ${ }^{51}$

It is not the case that older people in work block jobs for younger people. ${ }^{52}$

\footnotetext{
${ }^{49}$ Ibid, p 34.

${ }^{50}$ R J Stone Human Resource Management (Milton: John Wiley \& Sons Australia, 1998) p 265 quoted in L Morris 'Performance appraisals in Australian universities - imposing a managerialistic framework into a collegial culture' [2005] AIRAANZ 2005: Proceedings of the Conference of the Association of Industrial Relations Academics of Australia and New Zealand 387, p 390.

${ }^{51}$ DWP 'Employing older workers: an employer's guide to today's multi-generational workforce' $\mathrm{p} 10$.

${ }^{52}$ BIS, above n 31, p 2.
} 
However, in enterprises with a fixed number of positions (including academia), it is possible that longer work careers for older workers will limit opportunities for others. While recognizing that the number of jobs in higher education is not as finite as those in one company, Manfredi and Vickers argue that

the number of positions [in higher education] cannot just expand to meet demand for jobs. If senior positions are occupied by older workers, then it will be difficult for younger staff to gain promotion. Budgetary constraints can mean that it is not feasible for departments to make appointments at senior salary levels until there are vacancies to be filled. ${ }^{53}$

Therefore, the 'fair innings' argument ${ }^{54}$ should perhaps be applied to the higher education sector as a whole. ${ }^{55}$

Concern about a lack of opportunities for younger academics is supported by empirical and anecdotal evidence of the UK academic employment market, which indicates that there are limited opportunities for early career academics in the UK, with many researchers experiencing a lack of employment security and limited prospects upon completing their $\mathrm{PhD} .{ }^{56}$ The majority of UK PhD graduates leave academia, either due to a

\footnotetext{
${ }^{53}$ Manfredi and Vickers, above n 3, p 346.

${ }^{54}$ That is, the idea that policies should take into account all advantages an individual has experienced cumulatively over their life: Fredman, above n 46, p 47. By this reasoning, older workers, who have 'had their chance' in the labour market, need to retire to make way for the next generation.

${ }^{55}$ Manfredi and Vickers, above n 3, p 347.

56 See, for example, C Armstrong 'Lack of job security: $\mathrm{PhD}$ students reject academia' <http://www.jobs.ac.uk/blogs/just-higher-ed/2009/03/16/lack-of-job-security-phd-students-reject-academia/> accessed 24 September 2013.
} 
lack of opportunities in universities or better opportunities in the private sector. ${ }^{57}$ Indeed, of UK-domiciled doctoral graduates from 2003-2007 working in the UK, only $23 \%$ of those surveyed worked as research staff in higher education institutions and $14 \%$ were employed as lecturers in higher education. ${ }^{58}$

That said, limited opportunities in higher education for younger academics preceded the abolition of the DRA: the question is whether the removal of the DRA will exacerbate the issue. As Table 3 demonstrates, few academics presently work into their 60 s, with academics aged 61 and over constituting only $8.7 \%$ of the academic workforce in the UK, and $5.1 \%$ of full time staff.

\section{Table 3 about here}

Therefore, at present, it is unlikely that older academics are significantly limiting opportunities for younger workers. That said, while older workers represent a fairly small proportion of the UK academic workforce, this figure has still increased significantly over time: the number of academic staff over the age of 66 more than doubled between 2003-04 and 2010-11. ${ }^{59}$ However, it does not appear that the UK academic workforce is ageing faster than the general population, and the age profile of permanent academic staff in England remained broadly stable between 1997 and $2010 .^{60}$ That said, if the proportion of older

\footnotetext{
${ }^{57} \mathrm{~S}$ Lynch 'Why PhD graduates are opting for a life in the fast lane' The Independent (21 September 2007) $<$ http://www.independent.co.uk/student/postgraduate/why-phd-graduates-are-opting-for-a-life-in-the-fast-lane464546.html> accessed 24 September 2013.

${ }^{58} \mathrm{~K}$ Haynes, J Metcalfe and T Videler 'What do researchers do? First destinations of doctoral graduates by subject' (2009) p 8.

${ }^{59}$ Universities UK 'Patterns and trends in UK higher education 2012' (London: 2012) p 18.

${ }^{60}$ Higher Education Funding Council for England 'The higher education workforce framework 2010' (London: 2010) p 28.
} 
academics were to increase dramatically in coming years, this could have consequences for younger academics.

The UK government's response to concerns regarding reduced opportunities for younger workers is that: 'Where there are genuine succession planning considerations ... employers could consider retaining a retirement age if it can be objectively justified'. ${ }^{61}$ This is the approach that has been adopted by the Universities of Oxford and Cambridge, where promoting fairness between the generations is a key justification for the use of a retirement age for academics:

The EJRA is considered to provide a proportionate means of ... promoting intergenerational fairness and maintaining opportunities for career progression for those at particular stages of a career, given the importance of having available opportunities for progression across the generations, in order, in particular, to refresh the academic, research and other professional workforce and to enable them to maintain the University's position on the international stage. ${ }^{62}$

The University considers that [the EJRA] is important to ensure inter-generational fairness, ... to ensure that the University continues to work towards a diverse workforce and to refresh the academy in providing opportunities for career development to those at an early stage of their academic career. ${ }^{63}$

\footnotetext{
${ }^{61}$ BIS, above n 31, p 7.

62 Personnel Services, University of Oxford 'Aim of EJRA' (Personnel Services, 26 October 2011) <http://www.admin.ox.ac.uk/personnel/end/retirement/acrelretire/ejraaim/> accessed 24 September 2013.

${ }^{63}$ Human Resources Division, University of Cambridge 'Statement of policy' (University of Cambridge, 31 May 2012) <http://www.admin.cam.ac.uk/offices/hr/policy/retirement/statement.html> accessed 24 September
} 


\section{c) Workforce planning}

Abolition of the DRA may also lead to difficulties in workplace and succession planning, particularly if mandatory retirement has been used previously as a tool in workforce management. ${ }^{64}$ However, employee attrition is not solely dependent on retirement: employees can leave an employer for a variety of reasons, the majority of which are unrelated to retirement. Planning on the basis of a 'known attrition profile' due to mandatory retirement ignores the broader transience of modern employment. ${ }^{65}$ As individual career paths become increasingly complex and heterogeneous ${ }^{66}$ and the idea of a 'job for life' is dismissed as a thing of the past ${ }^{67}$ workforce planning will become more complicated for employers. On its own, mandatory retirement is unlikely to make workforce planning substantially easier, particularly if mature HR processes are not in place to back it up. ${ }^{68}$

2013. For an analysis of whether these aims and policies are likely to be upheld if challenged, see Manfredi and Vickers, above $\mathrm{n} 5$.

${ }^{64}$ See B Hepple 'Age discrimination in employment: implementing the Framework Directive 2000/78/EC' in S Fredman and S Spencer (eds), Age as an Equality Issue: Legal and Policy Perspectives (Oxford: Hart, 2003) p 91; R Posner Aging and Old Age (Chicago: University of Chicago Press, 1995) p 324; R A Epstein Equal Opportunity or More Opportunity? The Good Thing about Discrimination (London: Civitas, 2002) p 28; R (on the application of Age UK) v Secretary of State for Business, Innovation \& Skills \& Ors [2009] EWHC 2336 (Admin) (25 September 2009) [72]-[76].

${ }^{65}$ Manfredi and Vickers, above n 3, p 347.

${ }^{66}$ M Kohli 'The world we forgot: a historical review of the life course' in V W Marshall (ed), Later Life: The Social Psychology of Aging (Beverly Hills: Sage, 1986) p 295; M Kohli 'The institutionalization of the life course: looking back to look ahead' (2007) 4 Research in Human Development 253, p 261.

${ }^{67}$ G Naegele and others A New Organisation of Time over Working Life (Luxembourg: Office for Official Publications of the European Communities, 2003) p 78.

${ }^{68}$ Mature HR processes in this context might include regular conversations between employers and employees to ascertain future career intentions and obtain feedback about wellbeing at work. 


\section{d) Budgetary issues}

Finally, the abolition of the DRA may have financial consequences for universities, as older workers may be more expensive than their younger counterparts. Indeed, budgetary factors led to most requests to continue working beyond the DRA being rejected in UK universities. $^{69}$

These concerns are reflected in the salary range of full time academic staff in the UK. According to Higher Education Statistics Agency data for 2012-13, of full time academic staff aged 66 and over in the UK, 57.6\% were on a contract salary exceeding $£ 56,467$ (the top rate surveyed), ${ }^{70}$ compared with $20.8 \%$ of full time academic staff across all age groups. A substantial proportion of academics over the age of 55 were also in the same wage category, representing $52.4 \%$ of full time academics aged $61-65$, and $41.5 \%$ of full time academics aged 56-60. In contrast, only $2.1 \%$ of full time academics aged $31-35$ were on a similar wage. While these trends are understandable, given the extended period of time required to build an academic career, it demonstrates that older academics can be costly to universities. The abolition of the DRA may increase staff expenses for universities as older academics remain in employment.

\section{4) Comparative experience: the case of Australia}

Given these concerns, it is worth considering whether these challenges and implications have eventuated in another jurisdiction with a longer history of operating without a DRA. Further, it is useful to assess whether there are any comparative lessons for how UK universities might operate without a DRA.

\footnotetext{
${ }^{69}$ Manfredi and Vickers, above n 3, p 364.

${ }^{70}$ However, with the low employment rates for older academics in the UK, this only equates to 330 academics.
} 


\section{a) Legislative provisions}

Compulsory retirement was abolished in Australia progressively over the 1990s and 2000s. ${ }^{71}$ Under the current legislative provisions, compulsory retirement is prohibited within Australian workplaces, including universities. ${ }^{72}$ The Age Discrimination Act 2004 (Cth) s 18(2) provides:

It is unlawful for an employer or a person acting or purporting to act on behalf of an employer to discriminate against an employee on the ground of the employee's age ... (c) by dismissing the employee ....

However, discriminatory behaviour is exempt from the Act where the employee is 'unable to carry out the inherent requirements of the particular employment because of his or her age' (s $18(4)-(5)) .^{73}$

Compulsory retirement is also prohibited by the Fair Work Act 2009 (Cth), which provides that an employer:

\footnotetext{
${ }^{71}$ Rosenman and McDonald, above n 2. See, for example, Industrial Relations Reform Act 1993 (Cth), AntiDiscrimination (Amendment) Act 1994 (NSW), Abolition of Compulsory Age Retirement (Statutory Officeholders) Act 2001 (Cth), Age Discrimination Act 2004 (Cth).

${ }^{72}$ While some state and territory legislation still contains mandatory retirement as an exception to the principle of age equality (see Anti-Discrimination Act 1998 (Tas) s 35; Anti-Discrimination Act (NT) s 36), the passage of the Age Discrimination Act 2004 (Cth) has likely rendered the sections irrelevant: N Rees, S Rice and D Allen Australian Anti-Discrimination Law (Annandale: Federation Press, 2nd edn, 2014) pp 61-2. See further Age Discrimination Act 2004 (Cth) ss 10, 12; Australian Constitution s 109.

${ }^{73}$ For further on 'inherent requirements', see Qantas Airways Ltd v Christie (1998) 193 CLR 280. In relation to the limitations of the Age Discrimination Act 2004 (Cth) as a means of addressing discriminatory behaviour, see T MacDermott 'Challenging age discrimination in Australian workplaces: from anti-discrimination legislation to industrial regulation' (2011) 34 UNSW Law J1 182.
} 
must not take adverse action [including dismissal] against a person who is an employee, or prospective employee, of the employer because of the person's ... age (s $351(1))^{74}$

Again, this prohibition does not apply to action that is 'taken because of the inherent requirements of the particular position concerned' (s 351(2)(b)). ${ }^{75}$

\section{b) Consequences of abolishing retirement ages for university academics}

The abolition of compulsory retirement in Australian universities was not always a smooth process. ${ }^{76}$ At the time, Rosenman and McDonald wrote that 'tertiary administrators are concerned about doddery old professors taking up office space, mumbling in front of classes and presenting a significant danger in laboratories. ${ }^{77}$ Given universities have now had an opportunity to adjust to this new structure, it is informative to consider what sort of equilibrium (if any) has been achieved in relation to the employment of older academics.

\footnotetext{
${ }^{74}$ The Fair Work Act 2009 (Cth) also prohibits modern awards and enterprise agreements from containing clauses which discriminate on the basis of age: ss 153, 194; see Australian Catholic University Limited T/A Australian Catholic University [2011] FWA 3693 (10 June 2011).

${ }^{75}$ In relation to practical and interpretative issues associated with relying on the Fair Work Act 2009 (Cth) as a means of addressing age discrimination, see MacDermott, above n 73. Judges and military personnel may still be subject to compulsory retirement: see Australian Law Reform Commission 'Grey areas - age barriers to work in Commonwealth laws' (Sydney: 2012) Discussion Paper 78 paras 2.105-2.116. These provisions have led to some indirect legal challenges: see Commonwealth of Australia v Human Rights \& Equal Opportunity Commission [1999] FCA 616 (11 May 1999); Re Peter Albert Langman and Defence Force Retirement and Death Benefits Authority [1987] AATA 184 (12 May 1987).

${ }^{76}$ See, for example, Ivory v Griffith University [1997] QADT 4 (30 January 1997); Re The Queensland AntiDiscrimination Act 1991 [1997] QSC 71 (29 April 1997).

${ }^{77}$ Rosenman and McDonald, above n 2, p 63.
} 
Further, it is revealing to consider which (if any) of the concerns raised prior to the abolition of the DRA in the UK (discussed above) are evident in the Australian context.

To analyse these issues, this article draws on statistical evidence, qualitative expert interviews with the NTEU and organisational case studies of six Australian universities. A case study methodology was selected for this research as it enabled the complexity of the employment of older academics to be studied in depth and interpreted in the organisational context. ${ }^{78}$ Cases were sampled purposively to reflect different organisational and university structures that were predicted to influence their exposure and response to an ageing academic workforce: both established, research-intensive universities and newer, more teachingfocused universities were selected for study. A final determination and selection of cases was made based on practical considerations, including whether the university was physically accessible to the researcher. ${ }^{79}$ The case study organisations included four Group of Eight ${ }^{80}$ universities and two members of the Australian Technology Network ${ }^{81}{ }^{82}$

\footnotetext{
${ }^{78} \mathrm{~J}$ Feagin, A Orum and G Sjoberg 'Introduction: the nature of the case study' in J Feagin, A Orum and G Sjoberg (eds), A Case for the Case Study (Chapel Hill: University of North Carolina Press, 1991) pp 7-13; H Simons Case Study Research in Practice (Los Angeles: SAGE, 2009) p 23.

${ }^{79}$ M Q Patton Qualitative Evaluation and Research Methods (Newbury Park: Sage, 2nd edn, 1990) p 181.

${ }^{80}$ A 'coalition of leading Australian universities', 'distinguished by depth and breadth in research': see https://go8.edu.au/page/go8-indicators.

${ }^{81}$ The Australian Technology Network 'brings together five of the most innovative and enterprising universities in the nation': see http://www.atn.edu.au/About-ATN/. Two other universities were also invited to participate in the study (a private university and a newer, teaching-focused institution), however neither responded to the researcher's communications.

${ }^{82}$ In this paper, a classification scheme is used to enable the broad identification of universities while still maintaining source and case study anonymity. Universities have been classified as being part of the Group of Eight (G8) or Australian Technology Network (ATN) and allocated a letter (from a to d). So the first Group of Eight university is identified with G8a.
} 
The case studies included semi-structured interviews with Directors or senior members of the universities' Human Resources Units and a documentary review of university policies and other documents ${ }^{83}$ to add depth to the interview data, enrich the researcher's understanding of the organisational context, further scrutinise the culture of the organisation ${ }^{84}$ and corroborate, augment and clarify the evidence collected through the interviews. ${ }^{85}$

Drawing on this empirical evidence, the consequences of abolishing retirement ages for academics in Australia will be considered in relation to six factors: workforce participation rates for older academics; financial costs for universities; age discrimination claims; use of, and dismissals based on, capability and performance measures; workplace and succession planning; and the impact on younger workers.

\section{i) Workforce participation rates for older academics}

Workforce statistics indicate that a substantial proportion of Australian university academics are now remaining in employment beyond the age of 65. As illustrated in Table 4, in 2012, 2,346 Australian academics were aged 65 or over (or $4.66 \%$ of the total academic workforce). In contrast, in 2012-13, academics aged 66 and over constituted only $0.46 \%$ of the full time UK academic workforce (see above). This trend also extends to those below the age of 65: in Australia, those aged 55+ comprise $25.65 \%$ of all academic staff, as compared with the UK, where those aged $56+$ represent only $14.9 \%$ of the full time academic workforce.

\footnotetext{
${ }^{83}$ See Patton, above n 87, p 467.

${ }^{84}$ Simons, above n 79, p 63.

${ }^{85} \mathrm{R}$ Stake 'Qualitative case studies' in Y Lincoln and N Denzin (eds), Strategies of Qualitative Inquiry (London: SAGE, 3rd edn, 2008) p 133; R K Yin Case Study Research: Design and Methods (London: SAGE, 5th edn, 2013) p 107.
} 


\section{Table 4 about here}

This national disparity may be related to the earlier abolition of mandatory retirement in Australia. Indeed, as Table 5 demonstrates, the percentage of total academic staff at Australian universities aged over 64 has increased from $0.96 \%$ in 1997 to $4.66 \%$ in 2012 . On the face of it, the abolition of mandatory retirement may have contributed to the substantial growth in the number of older academics in Australia.

\section{Table 5 about here}

However, these figures may also reflect the particular demographic challenge facing Australian universities. The significant growth in the Australian academic workforce in the 1960s and 1970s has led to an academic population typified by 'age heaping', or a concentration of academics in particular age groups. ${ }^{86}$ It has been projected that Australian universities would lose between a fifth and a third of their staff due to retirement in the first decade of the 21 st century, ${ }^{87}$ that half of the Australian academic workforce would retire in the next 15 years $^{88}$ and that 16,400 new staff would be needed just to replace those retiring over the next 20 years, in addition to those required for increased student participation. ${ }^{89}$ In an online survey of Australian academics, $20.5 \%$ indicated that they intended to retire in the next five to ten years. ${ }^{90}$ It is therefore predicted that Australian universities will face a

\footnotetext{
${ }^{86}$ G Hugo 'Demographic trends in Australia's academic workforce' (2005) 27 Journal of Higher Education Policy and Management 327, p 332.

${ }^{87}$ Ibid, p 339.

${ }^{88} \mathrm{E}$ Bexley, R James and $\mathrm{S}$ Arkoudis 'The Australian academic profession in transition: addressing the challenge of reconceptualising academic work and regenerating the academic workforce' (Melbourne: 2011) p 4.

${ }^{89}$ Ibid, p 3.

${ }^{90}$ Ibid, p 17.
} 
'massive challenge in academic staff recruitment' in coming years due to the loss of a 'substantial proportion' of academic staff. ${ }^{91}$ Concerns have also been raised that there are insufficient younger academics to fill the growing vacancies, representing a 'lost generation' of academics in Generation X. ${ }^{92}$ As a result of these demographic trends, it is unsurprising that older workers are strongly represented in the Australian academic population. Further, it is logical that Australian universities would wish to retain older academics who are good performers. $^{93}$

These trends were also evident in the case study organisations: in those universities, the percentage of academics over 50 ranged from $30 \%$ of academic staff (G8a) to $45 \%$ of academic staff (ATNb). Where recorded, the percentage of academics over 65 ranged from $4.8 \%$ of academic staff (G8d) to $5.1 \%$ of academic staff (ATNa). ${ }^{94}$ This is broadly consistent with the sector-wide statistics presented above. According to one respondent, 50 was 'still the sweet spot' for a university's age profile, as academics have not yet realised their full potential in their 40s (G8b). Therefore, Australian universities appear to value the experience and skills of their older academic workforce.

Similarly, older academics increasingly wish to remain in work in Australia: the universities were united in the belief that academics do not generally wish to retire. According to one, 'academics are a very, very different breed of individuals' compared to ordinary employees, as the 'great majority' never stop working (G8b). Respondents attributed this to the fact that

\footnotetext{
${ }^{91}$ Hugo, above n 94, p 327.

92 Ibid, p 340. These concerns have been resoundingly rejected by the NTEU. See further Part 4b(vi).

${ }^{93}$ Ibid. Indeed, there is recognition that higher teaching loads are more likely to be managed successfully by experienced academic staff: Ibid.

${ }^{94}$ One university did not centrally monitor workforce demographics, though each academic manager would know the statistics for their employees (G8b).
} 
academics 'get paid to do what they love', and are always at work (G8b). Academia is 'more than a job ... [it's] a way of life' (ATNb). As a result, academics never want to stop being at work (or to retire) (G8b) and, even where academics do retire, they 'don't see themselves as retired' (G8d). While some universities were not being 'inundated with everyone staying on' (ATNa), others noted that 'people never leave' (G8c) and '60 is the new 50' for academics (G8d).

Thus, while Australian universities have experienced a significant increase in the proportion of older academic staff since 1997, this may be partly the result of Australia's particular demographic challenges in academia, and partly related to academics' desire to remain in employment. It is thus possible that a similar trend will occur in the UK with the removal of the DRA (though perhaps not to the same extent). This may have substantial implications for the UK higher education sector.

\section{ii) Financial costs for universities}

While it is desirable to retain older academics' skills and experience, the number of older academics in Australia is likely to have significant cost implications for universities. Table 6 depicts the classifications of Australian academic staff by age group. Of academic staff aged over 64 in 2012, 1,415 (or 60.3\%) were classified above the level of senior lecturer. This may be compared with academic staff aged 35-39, of whom only $7 \%$ were classified above the level of senior lecturer in 2012. Overall, those aged 65+ comprised 10.63\% of Australian academics above senior lecturer level in 2012, despite only representing $4.66 \%$ of the total workforce.

Table 6 about here 
As Bexley, James and Arkoudis note, the number of academics classified as Senior Lecturer or above is the only group to have increased in size as a proportion of the total academic workforce since 1996, largely due to the ageing academic population. ${ }^{95}$ This has created 'top heavy' and expensive academic structures, which may limit the ability of universities to employ young academics: the wages for the most senior academics are around double those of a junior (Level A) employee. ${ }^{96}$ This may have serious consequences for university budgets and overall staffing costs. Indeed, the Australian higher education sector has experienced an increase in staffing expenditure relative to revenue since 2010, with the average staffing cost rising from $50.71 \%$ of revenue in 2010 to $53.79 \%$ in $2012 .{ }^{97}$ Further, if an increasing wage bill limits the number of junior academics universities can employ, this may also affect universities' capacity to respond to increasing student populations, as junior academics are (rightly or wrongly) often made responsible for teaching large undergraduate courses and shouldering significant teaching loads.

\section{iii) Number of age discrimination claims}

In Australia, age discrimination claims can be made under federal, state or territory antidiscrimination laws and, in the area of employment, under the Fair Work Act 2009 (Cth). Therefore, the number of age discrimination claims needs to be considered at federal and state/territory level and in relation to employment claims. Under the federal Age Discrimination Act 2004 (Cth), employees may make a complaint of age discrimination to the Australian Human Rights Commission ('AHRC'). The number of age discrimination complaints received by the Commission in the last five years is presented in Figure 1.

\footnotetext{
${ }^{95}$ Bexley, James and Arkoudis, above n 96, p 4.

${ }^{96}$ Ibid.

${ }^{97}$ Though this is still a reduction from the average of $57.53 \%$ in 2008: S Andrews, H Wong and D Gullo 'Universities HR benchmarking program 2013: companion report' (Melbourne: 2013) p 5.
} 


\section{Figure 1 about here}

As Figure 1 demonstrates, the number of age discrimination complaints received by the AHRC has remained fairly constant since 2008. Further, complaints under the Age Discrimination Act 2004 (Cth) make up only a small proportion of the total complaints received by the Commission: in 2012-13, 2177 complaints were received overall, meaning age discrimination was raised in only $7.2 \%$ of complaints. This percentage has also remained relatively constant over the last five years, as depicted in Figure 2.

\section{Figure 2 about here}

Of these complaints, an even smaller proportion relate to employment, and even fewer are likely to relate to older workers. In 2012-13, 103 (or 57.5\%) of complaints received by the AHRC under the Age Discrimination Act 2004 (Cth) related to employment. ${ }^{98}$ This indicates $^{2}$ that the number of age discrimination complaints to the AHRC arising from employment is fairly low, and is not increasing significantly over time.

In relation to the Fair Work Act 2009 (Cth), only 56 or $7 \%$ of discrimination complaints received by the Fair Work Ombudsman between 1 July 2009 and 30 June 2010 related to age. ${ }^{99}$ While age was the second most common attribute specified in complaints in $2010-11$, this still represented only 152 complaints, or $13 \%$ of all complaints. ${ }^{100}$ Age was not a most

\footnotetext{
${ }^{98}$ Australian Human Rights Commission ‘Annual report 2012-2013’ (Sydney: 2013) p 143.

${ }^{99}$ Fair Work Ombudsman 'Overview of discrimination function 2009-10' (2011) p 2.

${ }^{100}$ Fair Work Ombudsman 'Annual report 2010-11' (Canberra: 2011) p 41.
} 
common attribute specified in 2011-12 or 2012-13, indicating that 2010-11 may have been an exceptional year for age complaints.

At the State level, the NSW Anti-Discrimination Board received 365 enquiries (or $6.3 \%$ of all enquiries) relating to age discrimination in $2012-13,212$ of which related to employment. ${ }^{101}$ However, the Board received only 35 formal complaints of age discrimination over the same period (representing $3.32 \%$ of all complaints and $6.22 \%$ of employment complaints). ${ }^{102}$

In Victoria, the Victorian Equal Opportunity and Human Rights Commission received 320 enquiries relating to age discrimination against older people in $2012-13 .^{103}$ That same year, the Commission received 84 complaints relating to age in employment, down from 109 in 2011-12. ${ }^{104}$ This represents $3.14 \%$ of all complaints received by the Commission, and $4.72 \%$ of all employment complaints. ${ }^{105}$

Overall, these figures indicate that age discrimination complaints are relatively infrequent in Australia: while a number of queries are received at both state and federal level in any given year, few translate to formal complaints, and many complaints do not relate to the field of employment. ${ }^{106}$ Further, few of these complaints specifically relate to universities: in Victoria (the only jurisdiction in which such data is available), only 77 discrimination complaints

\footnotetext{
${ }^{101}$ Anti-Discrimination Board of NSW 'Annual report 2012-13' (Sydney: 2013) pp 11-12.

102 Ibid, p 14.

${ }^{103}$ Victorian Equal Opportunity and Human Rights Commission 'Annual report 2012-13' (Melbourne: 2013) p 41.

${ }^{104}$ Ibid, p 43.

105 Ibid.

${ }^{106}$ This may also reflect institutional limitations: the two-stage enforcement model for discrimination claims in Australia may reduce the number of cases: see further Rees, Rice and Allen, above n 72, p 8.
} 
were made against all educational institutions (including universities) across all grounds in $2012-13 .^{107}$

Similarly, reported cases against universities on the basis of age discrimination are rare. Only two such cases were reported between 2000 and 2013: in Rochas $v$ The University of Sydney, ${ }^{108}$ the claimant alleged age discrimination in the University's appointment processes; and in Vanden Driesen $v$ Edith Cowan University ${ }^{109}$ the applicant raised a claim of age discrimination in the context of a redundancy dispute. Overall, the statistics relating to claims and complaints of age discrimination, and the limited number of cases relating to age discrimination against universities, indicate that the removal of mandatory retirement has not led to a significant increase in age discrimination claims. Indeed, it appears that few age discrimination claims are brought against universities in Australia. However, this may not reflect an absence of age discrimination: according to the NTEU, older academics are often targeted for redundancy in Australian universities. While the union has considered bringing a claim of age discrimination in the past, 'enough members are always saying never stand between a 63 year old academic and [a] \$150,000 pay-out'. Financial incentives may deter older academics from alleging age discrimination. Further, institutional barriers, a lack of legal advice and/or difficulties proving discrimination may also deter older workers from bringing a claim.

The small number of reported age discrimination claims is consistent with the experience of the case study organisations: no university had experienced a significant number of age discrimination claims from older academics. Indeed, the majority could not recall any age

\footnotetext{
${ }^{107}$ Victorian Equal Opportunity and Human Rights Commission, above n 111, p 44.

108 [2004] NSWADT 14 (21 January 2004).

${ }^{109}$ [2012] FMCA 735 (10 October 2012).
} 
discrimination claims being brought against their institution: 'I can't think of any' (G8a, also $\mathrm{ATNb})$; others had not received an age discrimination claim in the last seven years (G8b) or the last decade (G8d) and did not see age discrimination claims as being 'a real problem' (ATNa). Instead, respondents perceived issues of gender and race to be more important for universities, being areas that receive legal claims 'much more frequently' (ATNa, also G8c, G8d).

Only one university noted experiencing legal difficulties in attempting to get a staff member to retire: in that case, the staff member was offered a pre-retirement contract and, when amicable discussions broke down, the academic went 'completely legal' (G8c). However, even in this case, the claim did not relate to age discrimination, but was more concerned with the kind of separation agreement to be negotiated with the university (G8c). That university had experience two to three claims in the last two to three years, though no claims were explicitly related to age discrimination $(\mathrm{G} 8 \mathrm{c})$. While a small number in absolute terms, the claims were very time consuming when they occurred (G8c).

\section{iv) Performance management and capability dismissals}

As with the UK, Australian universities have traditionally been ambivalent towards performance management structures. ${ }^{110}$ As Hughes and Sohler note, there is "considerable disagreement about whether the whole enterprise [of performance management and appraisal] is in fact feasible or desirable ... in the university context'. ${ }^{111}$ There has been

\footnotetext{
${ }^{110} \mathrm{G}$ Sharrock 'Performance management and cultural difference in the Australian university' (1999) 36 Asia Pacific Journal of Human Resources 87, p 87.

${ }^{111}$ C Hughes and C Sohler 'Can performance management work in Australian universities?' (1992) 24 Higher Education $41, \mathrm{p} 42$.
} 
'much anguish' about whether the 'special nature' of academic work, ${ }^{112}$ the special culture of universities ${ }^{113}$ or their characteristics and values ${ }^{114}$ are compatible with performance appraisal systems. In particular, academic freedom and collegial governance, which are arguably essential to the academic endeavour, may fundamentally conflict with the aims of performance management, and make it impracticable to implement within a university context. $^{115}$

Despite these concerns, performance appraisal was first introduced into Australian universities in 1988 by an industrial award of the Australian Industrial Relations Commission which linked pay increases to assessments of performance and introduced an academic appraisal system. ${ }^{116}$ The award was amended in 1990 to also include performance appraisals for developmental purposes. ${ }^{117}$ With the growth of enterprise bargaining, universities may now negotiate performance appraisal systems with union representatives at the local level, allowing greater diversity and flexibility between universities (and, potentially, the growth of the managerial prerogative at the local level). ${ }^{118}$ The growth of performance management in Australian universities has been linked with a broader shift towards 'a corporate-managerial model of mission statements and performance management' in the sector. ${ }^{119}$

\footnotetext{
${ }^{112}$ Ibid, p 43.

${ }^{113}$ Sharrock, above n 119.

${ }^{114}$ Hughes and Sohler, above n 120, pp 46-7.

${ }^{115}$ Ibid; Morris, above n 50, p 390; L Morris, P Stanton and J Mustard 'Rhetoric and reality: an examination of performance management in Australian universities' [2011] AIRAANZ 2011: Proceedings of the 25th Conference of the Association of Industrial Relations Academics of Australia and New Zealand 1, p 3.

${ }^{116}$ Morris, Stanton and Mustard, above n 124, pp 1, 4.

${ }^{117} \mathrm{Ibid}, \mathrm{p} 4$. Developmental performance appraisal is directed to 'enriching attitudes, experiences, and skills that improve the effectiveness of employees': see W R Boswell and J W Boudreau 'Separating the Developmental and Evaluative Performance Appraisal Uses' (2002) 16 Journal of Business and Psychology 391, p 392.

${ }^{118}$ Morris, Stanton and Mustard, above n 124, p 1.

${ }^{119}$ Morris, above n 50, p 388.
} 
While there is now a reasonable history of performance management in Australian universities, concerns have been raised regarding the effectiveness of its implementation. There is fundamental disagreement regarding whether performance management should pursue summative (judgmental) or formative (developmental) goals. ${ }^{120}$ While a survey of Australian business academics found that the vast majority (93\%) were supportive of the concept of performance management, and believed performance management should focus on staff development and motivation, their actual experience of performance appraisal systems had been as a 'controlling mechanism'. ${ }^{121}$ Stavretis argues that universities' inability to clearly articulate the purposes of performance appraisal and focus on its effective implementation has led to 'widespread cynicism and a ritual dance of compliance that demonstrates palpably low engagement' by staff. ${ }^{122}$ This is consistent with the NTEU's observations: 'I think most of the heads of school, although they wouldn't say it, see most of the performance management systems as a bit of a joke.'

Performance appraisal systems thus face significant practical challenges in their implementation. ${ }^{123}$ It is therefore unsurprising that the abolition of the academic retirement ages in Australia has not led to a significant increase in capability and performance-related dismissals. In the case study organisations, performance measures were not used more frequently to manage older academics. Respondents explicitly rejected any correlation

\footnotetext{
${ }^{120}$ Sharrock, above n 119, p 87; Morris, Stanton and Mustard, above n 124, p 3.

${ }^{121}$ Morris, Stanton and Mustard, above n 124.

${ }^{122} \mathrm{~L}$ Stavretis 'The dance of compliance: performance management in Australian universities' (RMIT University 2007) p 2 <http://researchbank.rmit.edu.au/view/rmit:9770> accessed 19 September 2013; see also L Morris 'From collegial engagement to performance management: the changing academic landscape in Australia' (Victoria University 2011) p ii.

${ }^{123}$ See further Stavretis, above n 131.
} 
between age and performance: that is 'just not right' (G8b) and older academics were 'performance managed like anybody else' (G8b). However, older academics may need to be 'moved on' if they were not willing to engage with new teaching methods or research (ATNa): some older academic staff want to remain at work and are in 'denial [of their] own capacity' to do so (ATNb). In these cases, it was easier to encourage someone to retire than to use 'harsher methods' such as performance management (ATNa).

Thus, the limited use of performance management for older academics may reflect the limited capacity (and inclination) of universities to effectively deploy performance measures. According to the NTEU, Australian universities are reluctant to use performance management for academics, and 'performance management in the sense that it leads to people being given the axe' is basically unheard of. However, this does not preclude informal performance-related discussions: 'It may well be that a head of school says to one of our members, "Look, I really reckon you're not cut out to be an academic, you should start looking for another job," or, "You're getting on a bit, ... maybe it's time you thought about retiring." I'm sure that sort of thing goes on and it leads to people leaving.'

Instead of using formal performance management processes, Australian universities are increasingly relying on redundancy as a 'proxy for performance' management (NTEU) (and, perhaps, as a proxy for mandatory retirement). According to the NTEU, 'the number of people who are performance managed (as distinct from conduct managed) out of the institutions is infinitesimally small.' This is backed up by turnover statistics for the sector: in 2012, 7.9\% of staff within Australian higher education ceased work due to 'Voluntary Employee Initiated Turnover' (down from 10.5\% in 2008), 6.4\% due to 'Fixed-term Contract Expiration' (contracts not being renewed), $0.96 \%$ due to 'Voluntary University Initiated 
Turnover' and $0.66 \%$ due to 'Involuntary University Initiated Turnover' (including performance and conduct management). ${ }^{124}$ However, the NTEU estimates that between half and two-thirds of 'voluntary terminations' in Australian universities 'are not voluntary at all': 'voluntary university initiated is essentially would you like to take this package or would you like us to sack you'. This reliance on 'packages' may have significant financial consequences for the university sector as a whole, and may limit the funds available for core university functions like teaching and research.

While there are few performance-related dismissals, the NTEU still believes that performance management has intensified academic work in Australia: 'these things cause people to work a lot harder and to stress a lot more than they used to, and it might mean that they're going to be declared redundant. So I'm sure it's increased work intensification.' This is concerning, as Australian university staff already exhibit high levels of psychological strain: in a 2002 survey, $50 \%$ of university staff were identified as being at risk of psychological illness (compared with $19 \%$ of the general population). ${ }^{125}$ In describing this survey, the NTEU observed: 'Obviously that's dated, but nobody would seriously suggest that anything's got better since then.'

\section{v) Workforce and succession planning}

The removal of mandatory retirement may have also complicated workforce and succession planning for Australian universities. Some universities are now investing significant time and energy in workforce planning, including by compiling annual workforce planning reports and

\footnotetext{
${ }^{124}$ Andrews, Wong and Gullo, above n 105, p 6.

${ }^{125}$ A H Winefield and others 'Occupational Stress in Australian Universities: A National Survey 2002' (2002) p 91.
} 
appointing dedicated workforce planners or workforce planning units. ${ }^{126}$ Again, this may reflect the significant demographic challenges facing Australian higher education: if half of the Australian academic workforce are to retire by $2025,{ }^{127}$ universities will need to put in place clear succession plans to address the likely loss of academic talent. Indeed, in this context, the abolition of mandatory retirement may help to relieve universities' succession planning problems, as there is the possibility that key staff will remain at work for a longer period.

The case study universities noted the challenge of workplace and succession planning with an ageing academic workforce. Respondents recognised the need to 'refresh the discipline' with younger, cheaper academics, who brought enthusiasm and new approaches to the university (G8b) and who were willing to engage with new methods of teaching and increase the university's research profile (ATNa, ATNb). Some universities proactively facilitated and promoted succession planning, conducting extensive workforce planning exercises to analyse the age profile and intentions of their workforce (ATNa, G8d) and, in one case, employing a specialist workforce planner (G8d). The structure of university pension schemes also gave universities some certainty for planning, as there were financial disincentives to stay at work

\footnotetext{
${ }^{126}$ See, for example, Charles Sturt University's Guidelines on Workforce Planning and Central Queensland University's Workforce Planning Framework see also University of South Australia 'Workforce planning at $\begin{array}{llllll}\text { UniSA' } & \text { (Human } & \text { Resources } & \text { Unit, } & 7 & \text { February }\end{array}$ <http://w3.unisa.edu.au/hrm/resources/planning/workforce.asp> accessed 15 January 2014; Australian National University 'Workforce planning' (Human Resources, 11 June 2013) <http://hr.anu.edu.au/employment-atanu/workforce-planning> accessed 15 January 2014; University of Tasmania 'Workforce planning' (Human Resources, December 2013) <http://www.human-resources.utas.edu.au/strategic-hr-management/workforceplanning > accessed 15 January 2014; University of Western Australia 'Workforce planning' (Human Resources, 8 January 2014) <http://www.hr.uwa.edu.au/policies/policies/workforce-planning> accessed 15 January 2014 ..

${ }^{127}$ Bexley, James and Arkoudis, above n 96, p 4.
} 
beyond the age of 60 under the defined benefit rules of some plans (ATNa). ${ }^{128}$ Universities also used pre- and post-retirement contracts to achieve some certainty as to when individuals would retire. ${ }^{129}$

The NTEU offered an alternative perspective: while some universities ${ }^{130}$ were proactively managing workforce planning, most do not see workforce planning as a central responsibility: 'The idea that there's actually a thing called the university that has to plan its workforce ... they just don't accept that.' Therefore, the absence of mandatory retirement is not complicating workforce planning - instead, workforce planning is just not occurring. This may reflect an over-supply of potential academic staff in Australia: 'There's 15,000-20,000 people in Australia who are fully qualified who could take an academic job tomorrow if there was one going, so why would you need to plan for anything?'

Further, while a lack of fixed retirement ages may complicate workforce planning, it is likely to be less detrimental than constantly shifting government priorities and targets. As universities are expected increasingly to shift and respond to government prerogatives, workforce planning has become highly challenging, as it is uncertain where funding will be targeted in future years and what goals universities will be required to meet in the short, medium and long term. In this uncertain environment, it is nearly impossible to plan for future workforce needs, with or without mandatory retirement ages in place. ${ }^{131}$

\footnotetext{
${ }^{128}$ However, government reforms have removed or are removing many of these disincentives, to encourage individuals to remain in employment for longer. This is likely to reduce the usefulness of pension schemes for workforce planning.

${ }^{129}$ These practical strategies for managing an ageing academic workforce will be discussed in a separate article.

${ }^{130}$ According to a Universities Australia survey, six.

${ }^{131}$ For some of the challenges associated with workforce planning, see Higher Education Funding Council for England, above n 60, s 3 .
} 


\section{vi) Impact on younger academics}

The distinct demographic trends in the Australian academic workforce (discussed above) may mean that intergenerational fairness is less of an issue in the Australian context than in the UK. If universities are struggling to recruit academics, there are likely to be plentiful opportunities for both younger and older academics. That said, the NTEU has firmly rejected the idea that universities are struggling to recruit academic workers:

there are $12,000 \mathrm{PhD}$ qualified people already working in the system on an hourly paid basis. So the idea that the ageing academic workforce means that there's some problem of labour supply, our view is that's just bunkum. ... There's an endless supply of further victims who are willing to volunteer [to be academics].

The NTEU's comments flag the issue of casualisation in Australian academia: while many younger workers are employed in academic roles, they are often consigned to insecure casual employment, with few later progressing to permanent academic posts. According to May et al, there are 67,000 casual academic staff in Australian academia, and 52\% of casual Australian academics are aged under 35, making the age profile of casual teaching staff 'considerably younger' than those in ongoing posts. ${ }^{132}$ Further, in 2012, nearly $87 \%$ of Level A academics were employed on fixed-term contracts. ${ }^{133}$ This indicates that younger and

\footnotetext{
${ }^{132} \mathrm{R}$ May and others 'The casual approach to university teaching: time for a re-think?' in K Krause and others (eds), Research and Development in Higher Education: Reshaping Higher Education (Gold Coast: Higher Education Research and Development Society of Australasia, 2011) p 194. However, as the NTEU notes, many casual staff (roughly 15\%) are aged over 55: 'that's one segment that people actually don't take notice of'. See further below.

${ }^{133}$ Andrews, Wong and Gullo, above n 105, p 5.
} 
junior academics are occupying less secure and more precarious roles than their older colleagues.

This trend is also reflected in the growth of senior ongoing academic positions in Australia. The number of senior academic posts (at Levels D and E) has risen from $19 \%$ of all academic posts in 1996 to $25 \%$ in $2008 .{ }^{134}$ This has occurred at the expense of lower level posts: the number of Level B positions has experienced a 'hollowing out' since 1996, dropping from $36 \%$ to $32 \%$ of academic positions over the same period. ${ }^{135}$ Overall, the total growth of noncasual staff between 1996 and 2008 at Level E has been 54\%, with Level B only experiencing $7 \%$ growth. This indicates that there were significantly more senior positions in Australian academia in 2008 than in 1996, with fewer junior academics being employed in non-casual positions as a result. Therefore, May et al argue that the 'lost generation' of academics described by Hugo is not lost: rather, they have just been consigned to 'casual, insecure teaching roles'. ${ }^{136}$

Thus, while there are opportunities for younger workers in Australian academia, these are in unstable and precarious employment. Casual employment is associated with isolation, limited professional opportunities, poor conditions, uncertainty and insecurity ${ }^{137}$ and may have negative health implications. ${ }^{138}$ It is at least arguable that this is related to the lack of retirement ages for older Australian academics: older academics tend to occupy permanent or tenured positions, reducing the number of such roles available for younger academics. Further, turnover in Australian universities appears to be decreasing, with average total

\footnotetext{
${ }^{134}$ May and others, above n 141, p 195.

135 Ibid.

${ }^{136}$ Ibid, p 196.

${ }^{137}$ See further ibid, p 192.

${ }^{138}$ See Winefield and others, above n 134, p 65.
} 
annual turnover dropping from $17.98 \%$ in 2008 to $15.89 \%$ in $2012 .{ }^{139}$ Turnover is also lower in more senior posts: the average turnover at Level E was 8.34\% in 2012.

However, according to the NTEU, turnover of around $16 \%$ is still high for any sector (see further the discussion of 'voluntary' turnover above). Further, casualisation is not restricted to younger academic workers: older academics are also often employed on casual contracts. Casualisation is increasing for all academic employees, as 'run[ning] a unit using casual employment is spectacularly cheaper' (NTEU). Therefore, with insecure government funding: 'The logic of the cost of presenting courses [with casual staff] is just so overwhelming that if you're short of money, then the thing to do is to casualise your teaching.' (NTEU) Therefore, these concerns may reflect broader issues with higher education in Australia, and be only tangentially related to the removal of mandatory retirement ages.

There was a mixed response from the case study universities regarding whether operating without a DRA had a negative impact on younger or aspiring academics. At some universities, intergenerational fairness was an issue in specific faculties (such as Arts), where it was easy to recruit academics and individuals tended to 'stay on', resulting in low turnover and making it 'tough' for younger academics to enter the system (ATNa, also ATNb). In these specific contexts, older academics could be perceived as 'occupying headcount' $(\mathrm{ATNb})$ and preventing the university from refreshing talent - '[we] can't recruit new blood' $(\mathrm{ATNb})$. Concerns were also raised that many young academics were employed on fixed term contracts, rather than holding permanent positions like their older counterparts (G8c, G8d). In these circumstances, it was more an issue of the quality and security of employment

\footnotetext{
${ }^{139}$ Andrews, Wong and Gullo, above n 105, p 6.
} 
available to younger academics (G8c) than whether work was available at all. Two respondents also expressed concern about the 'jobless generation', which 'really concerns me' (G8c, also G8d). Thus, for some universities concerns about a lack of intergenerational fairness were 'very much playing out' (G8d).

For other universities, intergenerational fairness was not seen as such an issue: when professors retired, the university would employ a (junior) lecturer to replace them, ensuring that younger generations were given the opportunity to enter academia (G8a). Further, promotion was based on merit, not the availability of positions or budgetary considerations, meaning it was not necessary for an older academic to retire before another could be promoted (G8a). However, this does imply that an ageing academic workforce could have significant budgetary ramifications, as older academics with a longer work history are more likely to be promoted to more senior (and expensive) positions, and there are few means of controlling the budget by limiting promotions. This has created 'top heavy' academic structures in many areas (G8a).

To ensure intergenerational fairness, one university adopted a different approach: older academics were approached and encouraged to retire and go on the 'pension payroll', thereby allowing a younger academic to be employed, in exchange for an honorary appointment (G8b). As an honorary appointee, academics receive all the benefits of employment - just without pay (G8b). This appeal to academics' altruism and the idea of intergenerational fairness was often successful - and it 'doesn't hurt to ask' (G8b). However, other universities doubted whether this approach could be effectively applied to their workforce (ATNa, ATNb, G8c). That said, one respondent felt it was 'incumbent on all of us to question whether [we 
have] reached [our] use-by-date', making intergenerational fairness a personal responsibility (G8c).

\section{5) Lessons for the United Kingdom}

This comparative perspective offers a number of lessons for universities and other employers in the UK, particularly in relation to 'intergenerational fairness' and 'dignity' arguments used to justify a retirement age in the Seldon case.

\section{a) Intergenerational fairness}

The significant 'age heaping' typifying Australian academia, the presence of a relatively generous defined benefit pension scheme and the projected retirement of many academics may have tempered any negative impact from the removal of mandatory retirement in Australian universities. That said, the removal of mandatory retirement may have reduced the number of ongoing academic posts available to younger workers, and the growth in the number of senior academic positions may have reduced the number of junior academics recruited. In this sense, the removal of default retirement ages may have had (and, indeed, be having) a very real impact on younger academics in Australia. That said, while there are concerns regarding intergenerational fairness in Australian universities, it is difficult to link the removal of mandatory retirement with any specific consequences in practice. Indeed, many of the issues raised above, particularly relating to the casualisation of academia, may reflect broader global trends in higher education, unrelated to the removal of the DRA.

Given UK academia is not experiencing the same demographic challenge as Australia, and there are already limited opportunities for early career academics in the UK, the removal of the DRA may make future prospects for younger UK academics particularly grim. Thus, 
concerns about intergenerational fairness expressed in the Seldon decision may well be warranted in the university context. ${ }^{140}$ While the 'fair innings' argument that underlies concerns about intergenerational fairness has been criticised extensively in the literature, ${ }^{141}$ the argument may hold where the internal labour market of a firm has rigid 'lines of progression' and 'internal career ladders', limited 'ports of entry' and workers have limited mobility between firms. ${ }^{142}$ This may be the case in some universities, supporting the adoption of mandatory retirement in selected UK institutions. Indeed, intergenerational fairness was a key aim behind the adoption of EJRAs at the Universities of Oxford and Cambridge (see further above).

\section{b) Dignity}

The second category of legitimate aims identified in the Seldon decision - dignity - was also used to justify the Oxford EJRA (though not that at Cambridge):

The EJRA is considered to provide a proportionate means of... in the context of the distinctive collegial processes through which the University is governed, avoiding invidious performance management and redundancy procedures to consider the termination of employment at the end of a long career, where the performance of

\footnotetext{
${ }^{140}$ Seldon v Clarkson Wright \& Jakes (A partnership) [2012] 2 CMLR 50, [56]-[57].

${ }^{141}$ Fredman, above n 46, p 47; see also Performance and Innovation Unit 'Winning the generation game: improving opportunities for people aged 50-65 in work and community activity' (London: 2000) pp 39-40; M Connolly 'The coalition government and age discrimination' [2012] Journal of Business Law 144, p 148; M Sargeant 'Distinguishing between justifiable treatment and prohibited discrimination in respect of age' (2013) 4 Journal of Business Law 398; E Dewhurst 'Intergenerational balance, mandatory retirement and age discrimination in Europe: how can the ECJ better support national courts in finding a balance between the generations' (2013) 50 Common Market Law Review 1333.

${ }^{142}$ See P B Doeringer and M J Piore Internal Labor Markets and Manpower Analysis (Lexington: Heath Lexington Books, 1971) p 3.
} 
the individual and/or the academic or other professional needs of the University have changed. $^{143}$

As noted above, justifying retirement provisions due to the need to avoid 'humiliating' performance management for older workers ${ }^{144}$ risks conflating age with capacity, and wrongly assumes that ageing is necessarily a process of decline and deterioration. ${ }^{145}$ Indeed, the Australian universities expressly rejected a link between age and declining capacity, and few universities used performance management to remove older academics. However, this may be because it is easier to encourage someone to retire than to use 'harsher methods' such as performance management. The limited use of performance management for older academics in Australia may reflect the limited capacity (and inclination) of universities to effectively deploy performance measures for all staff (and not just older academics).

A disinclination to use performance management may exacerbate the use of 'voluntary' redundancy to manage older staff. This risks treating all older academics as a group, rather than assessing individual capacity. As Fredman argues, 'it is ... an affront to the dignity of the individual to assume that he or she automatically shares the characteristics of everyone else in his or her age group'. ${ }^{146}$ Rather than relying on stereotypical assumptions of capability based on age, people should be treated as individuals, and have their capabilities assessed on an individual basis. Relying on redundancy as a performance management tool denies older workers the opportunity to respond to and address performance concerns, and risks breeding resentment and ill will among employees. Thus, the removal of mandatory retirement may

\footnotetext{
${ }^{143}$ Personnel Services, University of Oxford, above n 62.

${ }^{144}$ See Posner, above n 64, p 351; Epstein, above n 64, p 29.

${ }^{145}$ See further Schaie, above n 42, pp 319-20; C L Estes, S Biggs and C Phillipson Social Theory, Social Policy and Ageing: A Critical Introduction (Maidenhead: Open University Press, 2003) pp 18, 29.

${ }^{146}$ Fredman, above n 46, p 45.
} 
have implications for employees' dignity, though not in the way anticipated by the court in Seldon.

As a consequence, the removal of mandatory retirement for academics in Australia may be cultivating a negative work culture in universities and, contradictorily, encouraging age discrimination against older academics. These results therefore flag issues regarding how Australian universities are managing an ageing academic workforce in practice: the actual strategies being used by universities (such as 'voluntary' redundancies) raise significant concerns as to the equity of employment practices and how public funds are being used. According to the NTEU:

that concern which was raised in the early 90s by [university] management about the abolition of compulsory retirement, those concerns that were raised, I haven't heard those concerns raised probably in the last decade. So they've found a way to solve the problem, and yet they're probably also quite happy to have some of those people still working into their 70s because they're doing good work, but anyone that they don't like, think is getting too old, or they just think they can replace with somebody who's prepared to work harder perhaps, then they can get rid of them anyway using redundancy.

Thus, the removal of mandatory retirement may be encouraging cloaked age discrimination in universities, under the guise of 'redundancy' and, to a lesser extent, 'performance management'. How these processes are being used at an organisational level is beyond the scope of this article. However, it is an area that warrants serious consideration in future research. 
While the removal of mandatory retirement may be encouraging covert age discrimination, this is also a risk associated with adopting an EJRA. The implementation of an EJRA may lead to unequal treatment of older workers across different departments, and may require older workers to 'over-perform' compared with junior staff to justify their retention beyond retirement age. ${ }^{147}$ Thus, EJRAs may also perpetuate and exacerbate unequal treatment of older academics. There is a need for deeper exploration of how universities are managing an ageing academic workforce, and the implications of EJRAs and removing retirement ages for discriminatory practices against older workers.

\section{6) Conclusions and future research}

In sum, then, this article provides no definitive answers regarding what is likely to happen in the UK with the abolition of mandatory retirement. Based on the Australian experience, many concerns relating to extended academic working lives have not occurred: there has been no increase in age discrimination claims or the incidence of performance management. However, there has been an increase in the number of academics working past 65 , and universities may be using alternative, discriminatory methods (such as redundancy) to manage an ageing workforce. Extending working lives for older academics may also be affecting the employment prospects of younger academics, particularly in relation to the availability of permanent academic posts at junior levels.

Therefore, for UK universities electing not to adopt an EJRA, it will be necessary to carefully monitor workforce composition in the years to come. In particular, universities should be

\footnotetext{
${ }^{147}$ M Emery 'Academia, Oxford University and retirement' < http://www.withyking.co.uk/blog/academiaretirement-policy/> accessed 6 May 2014.
} 
attuned to whether younger academics are being disproportionately consigned to casual and short-term roles, and how many roles are being advertised at junior levels year-on-year. Further, universities should watch for the emergence of discriminatory practices that may act as a proxy for retirement, such as the use of 'voluntary' redundancy. It is not guaranteed that universities will experience negative consequences as a result of the removal of the DRA. Indeed, universities may experience improved staff retention, increased workforce morale and retain vital skills and experience. That said, it is imperative that the intergenerational impact of an ageing workforce is not disregarded. Future research should consider how UK universities are responding to the abolition of the DRA, and whether these risks are being actively managed in practice.

\begin{tabular}{|l|c|}
\hline \multicolumn{1}{|c|}{ Negative impacts of abolition of DRA } & Per cent experienced \\
\hline Blocking opportunities for younger workers & $48 \%$ \\
\hline Difficulties in succession planning & $29 \%$ \\
\hline More management time on performance & \\
management & $21 \%$ \\
\hline Increase in ill-health absence & $24 \%$ \\
\hline Increased cost of redundancies & $24 \%$ \\
\hline Increased cost of employee benefits & $4 \%$ \\
\hline Increase in age discrimination claims & \\
\hline
\end{tabular}

Table 1: Employer experiences of negative impacts from the abolition of the DRA (Source: Eversheds 2013) 


\begin{tabular}{|l|c|}
\hline \multicolumn{1}{|c|}{ Positive impacts of abolition of DRA } & Per cent experienced \\
\hline Improved retention of skills and knowledge & $33 \%$ \\
\hline Reduction in management time spent on & $22 \%$ \\
retirement procedures & $17 \%$ \\
\hline Savings in recruitment and training costs & $10 \%$ \\
\hline Improved worker morale & $9 \%$ \\
\hline Improved performance management of older & \\
workers & $6 \%$ \\
\hline Reduction in age discrimination claims & \\
\hline
\end{tabular}

Table 2: Employer experiences of positive impacts from the abolition of the DRA (Source: Eversheds 2013) 


\begin{tabular}{|l|l|l|l|}
\hline \multicolumn{1}{|c|}{ Age group } & \multicolumn{1}{|c|}{$\begin{array}{c}\text { Number of full } \\
\text { staff }\end{array}$} & \multicolumn{1}{c|}{$\begin{array}{c}\text { Number of part } \\
\text { staff }\end{array}$} & \multicolumn{1}{c|}{ Per cent of UK } \\
& \multicolumn{1}{|c|}{ time academic } & \multicolumn{1}{c|}{ academic staff } \\
\hline 30 and under & 15200 & 8925 & 13.0 \\
\hline $31-40$ years & 37940 & 14590 & 28.3 \\
\hline $41-50$ years & 35470 & 16090 & 27.8 \\
\hline $51-60$ years & 27600 & 13540 & 22.2 \\
\hline 61 and over & 6290 & 9935 & 8.7 \\
\hline Total & 122500 & 63090 & 100 \\
\hline
\end{tabular}

Table 3: Composition of UK higher education academic staff by age group and mode of employment, 2012-13 (Source: Higher Education Statistics Agency) 


\begin{tabular}{|l|l|l|}
\hline Age Group & Number of academic staff & Percentage of all academic staff \\
\hline$<25$ & 198 & 0.39 \\
\hline $25-29$ & 2,630 & 5.22 \\
\hline $30-34$ & 6,404 & 12.72 \\
\hline $35-39$ & 6,803 & 13.51 \\
\hline $40-44$ & 6,717 & 13.34 \\
\hline $45-49$ & 7,278 & 14.45 \\
\hline $50-54$ & 7,408 & 14.71 \\
\hline $55-59$ & 6,241 & 12.40 \\
\hline $60-64$ & 4,324 & 8.59 \\
\hline$>64$ (a) & 2,346 & 4.66 \\
\hline Total Persons & $\mathbf{5 0 , 3 4 9}$ & $\mathbf{1 0 0}$ \\
\hline
\end{tabular}

Table 4: Australian University academic staff by age, 2012 (Source: Australian Government Department of Industry) 


\begin{tabular}{|c|c|c|c|c|c|c|}
\hline & $\begin{array}{l}\text { Above } \\
\text { Senior } \\
\text { Lecturer }\end{array}$ & $\begin{array}{l}\text { Senior } \\
\text { Lecturer } \\
\text { (Level } \\
\text { C) }\end{array}$ & $\begin{array}{l}\text { Lecturer } \\
\text { (Level } \\
\text { B) }\end{array}$ & $\begin{array}{l}\text { Below } \\
\text { Lecturer } \\
\text { (Level } \\
\text { A) }\end{array}$ & $\begin{array}{l}\text { Total } \\
\text { Academic } \\
\text { Staff }\end{array}$ & $\begin{array}{l}\text { Percentage } \\
\text { of total } \\
\text { academic } \\
\text { workforce }\end{array}$ \\
\hline 1997 & 168 & 68 & 55 & 28 & 319 & 0.96 \\
\hline 1998 & 184 & 71 & 65 & 20 & 340 & 1.04 \\
\hline 1999 & 193 & 91 & 69 & 30 & 383 & 1.18 \\
\hline 2000 & 205 & 95 & 123 & 32 & 455 & 1.37 \\
\hline 2001 & 214 & 110 & 143 & 30 & 497 & 1.48 \\
\hline 2002 & 241 & 125 & 141 & 30 & 537 & 1.55 \\
\hline 2003 & 308 & 143 & 163 & 33 & 647 & 1.80 \\
\hline $2006^{148}$ & 603 & 258 & 207 & 51 & 1119 & 2.78 \\
\hline 2007 & 729 & 302 & 258 & 54 & 1343 & 3.18 \\
\hline 2008 & 816 & 318 & 280 & 55 & 1469 & 3.37 \\
\hline 2009 & 798 & 292 & 291 & 55 & 1436 & 3.15 \\
\hline 2010 & 1,002 & 324 & 315 & 69 & 1710 & 3.64 \\
\hline 2011 & 1,165 & 379 & 342 & 73 & 1959 & 4.05 \\
\hline 2012 & 1,415 & 437 & 415 & 79 & 2,346 & 4.66 \\
\hline
\end{tabular}

Table 5: Australian University academic staff over 64 by level of appointment, 19972012 (Source: Australian Government Department of Industry, author's own calculations)

${ }^{148}$ Data is not available for 2004 and 2005. 


\begin{tabular}{|l|l|l|l|l|l|}
\hline & Above & Senior & & Below & Sub-total \\
Age Group & Lecturer & Lecturer & Lecturer & Lecturer & Academic \\
& (Level C) & (Level B) & Level A) & Classifications \\
\hline$<25$ & 0 & $<5$ & $n p$ & 177 & $\mathbf{1 9 8}$ \\
\hline $25-29$ & np & $n p$ & $n p$ & 1,783 & $\mathbf{2 , 6 3 0}$ \\
\hline $30-34$ & 85 & 595 & 3,043 & 2,681 & $\mathbf{6 , 4 0 4}$ \\
\hline $35-39$ & 476 & 1,688 & 3,205 & 1,434 & $\mathbf{6 , 8 0 3}$ \\
\hline $40-44$ & 1,307 & 1,940 & 2,607 & 863 & $\mathbf{6 , 7 1 7}$ \\
\hline $45-49$ & 2,263 & 2,104 & 2,258 & 653 & $\mathbf{7 , 2 7 8}$ \\
\hline $50-54$ & 2,822 & 2,043 & 2,057 & 486 & $\mathbf{7 , 4 0 8}$ \\
\hline $55-59$ & 2,692 & 1,713 & 1,532 & 304 & $\mathbf{6 , 2 4 1}$ \\
\hline $60-64$ & 2,244 & 1,024 & 897 & 159 & $\mathbf{4 , 3 2 4}$ \\
\hline$>64(a)$ & 1,415 & 437 & 415 & 79 & $\mathbf{2 , 3 4 6}$ \\
\hline Total & $\mathbf{1 3 , 3 0 7}$ & $\mathbf{1 1 , 5 9 6}$ & $\mathbf{1 6 , 8 2 7}$ & $\mathbf{8 , 6 1 9}$ & $\mathbf{5 0 , 3 4 9}$ \\
\hline & & & & & \\
\hline
\end{tabular}

np: not published

Note: (a) includes a few staff whose ages are unknown

Table 6: Australian University academic staff by age and level of appointment, 2012 (Source: Australian Government Department of Industry) 